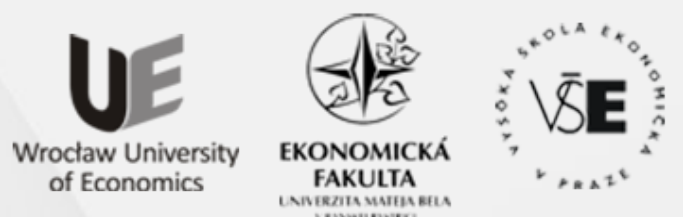

Conference Proceedings

Full TeXT PAPERS

edited by

Zofia Rusnak and Beata Zmyślona

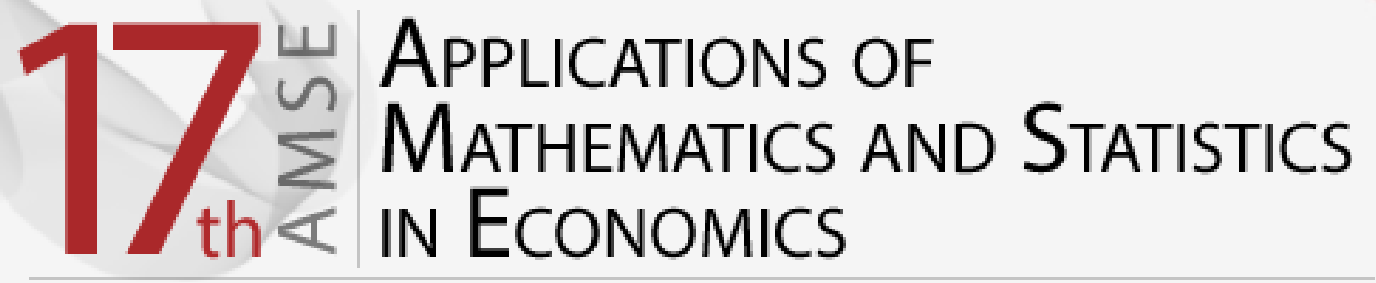

International Scientific Conference | Poland • 27-31 August 2014 
Scientific Committee

Richard Hindls, Stanislava Hronová, Rudolf Zimka, Walenty Ostasiewicz, Emília Zimková, Zofia Rusnak, Martin Bod'a

Organizing Committee

Beata Zmyślona, Cyprian Kozyra, Grzegorz Rogoziński, Kristýna Vltavská

\section{Reviewers}

Milan Bašta, Diana Bílková, Martin Bod'a, Joanna Dębicka, Tomáš Fiala, Jakub Fischer, Stanisław Heilpern, Karel Helman, Lenka Hudrlíková, Miroslav Hužvár, Nikola Kaspř́ková, Alena Kaščáková, Kamil Kladívko, Jindřich Klůfa, Pavol Král', Katarzyna Kuziak, Jana Langhamrová, Ivana Malá, Tomáš Marcinko, Luboš Marek, Miloš Maryška, Petr Mazouch, Zofia Mielecka-Kubień, Witold Miszczak, Petr Musil, Gabriela Nedelová, Walenty Ostasiewicz, Iva Pecáková, Viera Roháčová, Zofia Rusnak, Mária Stachová, Jana Špirková, Šárka Šustová, Jana Tepperová, Vladimír Úradníček, Kristýna Vltavská, Michal Vrabec, Dariusz Wawrzyniak, Henryk Zawadzki, Jaroslav Zbranek, Tomáš Zeithamer, Martin Zelený, Jan Zeman, Rudolf Zimka, Emília Zimková, Pavel Zimmermann, David Žižka

Layout

Martin Bod'a, Beata Zmyślona, Grzegorz Rogoziński

Front page design

Grzegorz Rogoziński

CD cover design

Beata Dębska

Articles published in the form submitted by the authors

All rights reserved. No part of this book may be reproduced in any form or in any means without the prior permission in writing of the Publisher

(C) Copyright by Wrocław University of Economics Wrocław 2014

ISBN 978-83-7695-421-9

Wydawnictwo Uniwersytetu Ekonomicznego we Wrocławiu

53-345 Wrocław, ul. Komandorska 118/120 www.ue.wroc.pl

Sprzedaż książek tel./fax 71 36-80-602

e-mail: econbook@ue.wroc.pl www.ksiegarnia.ue.wroc.pl 


\section{Contents}

Foreword

Diana Bílková: TL-Moments: Analogy of Classical L-Moments

Dagmar Blatná: Application of Robust Regression in the Analysis of Internet Access in European Countries

Martin Bod’a, Mária Kanderová: Rebalancing Issues in Tracking Error Variance Minimization

Martin Bod'a, Viera Roháčová: Application of Six Sigma Ideas to Timing Decisions at Financial Markets

Anton Dekrét, Rudolf Zimka: On the Price Hartwick's Task and Its Inverse in a Dynamic Model of an Economy with Exhaustible Resources

Joanna Dębicka, Agnieszka Marciniuk: Comparison of Reverse Annuity Contract and Reverse Mortgage on the Polish Market.

Petra Dotlačilová, Jitka Langhamrová: The Influence of Mortality Models for the Expected Future Life-time of Older People

Marek Ďurica, Lucia Švábová: Delta and Gamma for Chooser Options.

Vlastimil Farkašovský: New Concept of Pension Funds Performance Evaluation

Albert Gardon: The Normality of Weekly Relative Changes of the Freight Rate in Container Shipping.

Mária Grausová, Miroslav Hužvár, Jana Štrangfeldová: Healthcare Systems Efficiency in the Visegrád Group.

Stanisław Heilpern: Multiple Life Insurance - Pension Calculation

Alena Kaščáková, Gabriela Nedelová: Changes in Slovak Households' Economy

Igor Kollár, Pavol Král', Peter Laco: Methodology for Assessing Website Improvement in Corporate Environment.

Maciej Kostrzewski: Some Method of Detecting the Jump Clustering Phenomenon in Financial Time Series.

Cyprian Kozyra, Beata Zmyślona, Katarzyna Madziarska: Complementary Objective and Subjective Measures of Hospital Services Quality...

Pavol Král', Mária Stachová, Lukáš Sobíšek: Utilization of Repeatedly Measured Financial Ratios in Corporate Financial Distress Prediction in Slovakia

Ivana Malá: The Use of Finite Mixture Model for Describing Differences in Unemployment Duration

Lukáš Malec: Studying Economics and Tourism Industry Relations by Smooth Partial Least Squares Method Depending on Parameter. 
Tomáš Marcinko: Consequences of Assumption Violations Regarding Classical Location Tests.

Edyta Mazurek: The Income Tax Progression Depending on Social Insurance Contribution in Poland.

Petr Musil, Jana Kramulová, Jan Zeman: Regional Consumption Expenditures: An Important Starting Point for Regional Input-output Tables.

Katarzyna Ostasiewicz, Walenty Ostasiewicz: Good Life: From Political to Human Economy

Anna Sączewska-Piotrowska: Analysis of Poverty Transitions in Poland Using Multilevel Discrete-Time Event History Models

Martina Šimková, Petra Švarcová: Disadvantaged University Students in the Czech Republic.

Michal Široký: The Use of Short-term Business Statistics for Quarterly GDP Flash Estimates in the Czech Republic

Zdeněk Šulc, Hana Řezanková: Evaluation of Recent Similarity Measures for Categorical Data.

Lucia Švábová, Marek Ďurica: The Relationship Between the Finite Difference Method and Trinomial Trees

Kristýna Vltavská, Jaroslav Sixta: The Estimation of Final Consumption Expenditures

Lenka Vraná: Business Cycle Analysis: Tracking Turning Points

Janusz Wywiał: On Bayesian Testing in Auditing

Emília Zimková: Window Analysis of Supper-efficiency Change: Case of the Slovak Banking System ....

Beata Zmyślona: Statistical Modelling of the Impact of Diabetes on the Risk of Hospitalization 


\title{
UTILIZATION OF REPEATEDLY MEASURED FINANCIAL RATIOS IN CORPORATE FINANCIAL DISTRESS PREDICTION IN SLOVAKIA
}

\author{
PAVOL KRÁL \\ Matej Bel University in Banská Bystrica, Faculty of Economics, Department of Quantitative Methods and \\ Information Systems, Tajovského 10, 97590 Banská Bystrica \\ email: pavol.kral@umb.sk \\ MÁRIA STACHOVÁ \\ Matej Bel University in Banská Bystrica, Faculty of Economics, Department of Quantitative Methods and \\ Information Systems, Tajovského 10, 97590 Banská Bystrica \\ email: maria.stachova@umb.sk

\section{LUKÁŠ SOBÍŠEK} \\ University of Economics in Prague, Faculty of Informatics and Statistics, Department of Statistics and \\ Probability, W. Churchill Sq. 4, 13067 Prague 3 \\ email: lukas.sobisek@vse.cz
}

\begin{abstract}
One of the main approaches to financial analysis ex-ante is based on static classification models constructed using various statistical methods, e.g. discriminant analysis, logistic regression, decision trees. This approach takes into account quantitative characteristics of selected companies at the given time point, most typically three or four years prior the time of possible bankruptcy. If these characteristics are collected during a longer time period we can improve financial distress prediction models via incorporating dynamics into them. In the presented paper we focus on a simple case when only measurements of financial ratios in two consecutive time points are available. The main goal of our paper is to present how changes in financial ratios can be utilized in models predicting corporate financial distress. We illustrate our approach on two different data sets of Slovak companies in two different periods. Finally, we compare classification ability of models incorporating changes in financial ratios between two consecutive data points to classification ability of models estimated using a single time point data.
\end{abstract}

Key words: financial analysis ex-ante, changes in financial ratios, bankruptcy models.

DOI: 10.15611/amse.2014.17.17

\section{Introduction}

Many corporate financial distress and bankruptcy models have been constructed since wellknown Altman's Z-score was published in 1968 (Altman, 1968). In majority of cases these models are based on historical accounting data and corresponding financial ratios of a carefully selected sample of companies representing an economy of interest. Such models are constructed using different statistical and data mining methods, e.g. linear discriminant analysis, quadratic discriminant analysis, logistic regression, decision trees, random forests, neural networks, support vector machines, generalized additive models etc. The underlying idea is that the past values of appropriately selected financial and economic indicators are able to determine the financial health in the future. Unfortunately, such microeconomic approach has well known 
shortcomings. First, it is difficult to prepare suitable data sets for these models. Moreover, these models have a limited stability in longer time periods or they are unsuitable for economic environment with different and quickly changing conditions. Therefore recently more general approach combining accounting data, market-based and macro-economic data is advocated in literature (Hernandez, 2013; Tinoco, 2013) to explain corporate financial distress. The main goal of our paper is to provide the initial step in applying similar approach to an economic environment in Slovakia. We focus here on possibility to extend the classical bankruptcy models based on supervised statistical methods (Balcean, Ooghe, 2006, Brezigar-Masten 2012) by adding information about the dynamics of financial ratios to a training data set. We restrict ourselves to the case when only measurements of financial ratios in two consecutive time points are available. Furthermore, we estimate a classification model based on just one measurement. Thus, we are able to conclude if model incorporating changes in financial ratios provides better classification results.

The paper is organized as follows. In Section 2 we review basics of statistical learning methods used for model construction, namely principal components analysis, random forests and penalized logistic regression and present methodology incorporating changes in financial ratios into corporate financial distress prediction modelling. Section 3 describes two data sets of Slovak companies employed for illustrating our approach. Finally, in Section 4 we discuss classification ability of fitted models and usefulness of proposed methodology.

\section{Methodology}

Our data should satisfy the following conditions in order to add changes in financial ratios to our financial distress modelling. First, we need to know financial condition of a set of companies at the given time point, i.e. bankruptcy or liabilities in social or health insurance. According to them we divide the companies into two groups - "not in distress" and "in distress". Second, for both groups we need to know quantitative characteristics, e.g. financial ratios, of individual companies in two consecutive time points prior the given time point. Let us assume that our data set consists of $n$ companies and $m$ measured quantitative characteristics (except the status of a company, i.e. whether it belongs to "not in distress" or to "in distress" companies). Then differences in quantitative characteristics form a very simple description of their dynamics. We add these differences to our data set as new variables. The resulting data set includes $2 m$ variables describing quantitative characteristics and their corresponding changes dynamics. If the number of companies $n$ is not bigger than $2 m$ or if there are high correlations between variables, the next step of the analysis consists of principal component analysis (PCA). If $n$ is not bigger than $2 m$, we apply PCA to financial ratios and differences separately. In the case of supervised learning the number of components can be determined via cross-validation as a part of model fitting procedure (James et. al., 2013). But for simplicity of implementation and because we focus on prediction ability of our model, i.e. we are not interested in individual predictors in our model as far as its prediction ability is satisfactory, we prefer to take into account principal components preserving at least $90 \%$ of variability of original variables. In the last step of our analysis we construct a classifier based on selected supervised statistical learning methods. The error rate of the model is estimated using cross-validation. It is obvious that no classification method dominates all the other over all possible data sets (James et. al., 2013). In the given context, we decided to use penalized logistic regression, a generalization of the well-known logistic regression and tree-based method, random forest (Hastie et. al., 2001). Classifiers based on these methods are quit 
powerful still easy interpretable. Moreover, both methods are implemented in the wellestablished R packages and therefore easily deployable.

\subsection{Penalized Logistic Regression}

Similarly to ordinary logistic regression, penalized logistic regression is able to provide us with quite a good and easily applicable classification model, straightforwardly interpretable model coefficients and scoring in the form of conditional probabilities. Moreover, the shrinkage used in penalized logistic regression has the effect of reducing variance of estimated parameters and we do not need a separate procedure for selection of variables. As a consequence, we can get a model including only relevant variables (components in our case) and a more reliable estimation of classification error since over fitting is reduced. Penalized logistic regression is implemented in the statistical system $\mathrm{R}$ ( $\mathrm{R}$ Core Team, 2014), package glmnet (Friedman et al., 2010). As an input predictors matrix we used sparse matrix format created via package MatrixModels (Bates, 2012).

The penalized logistic regression is based on maximization of penalized log-likelihood in the following form:

$$
\sum_{\mathrm{i}=1}^{\mathrm{N}}\left[\mathrm{y}_{\mathrm{i}}\left(x_{i} \beta^{T}\right)-\log \left(1+e^{x_{i} \beta^{T}}\right)\right]-\lambda \sum_{j=1}^{p}\left|\beta_{j}\right|,
$$

where $\lambda$ denotes the penalization parameter, $\mathrm{x}_{\mathrm{i}}$ denotes the vector of inputs (it includes the constant term 1$), \beta=\left(\beta_{0}, \ldots, \beta_{N}\right)$ and $y_{i} \in\{0,1\}$.

The final solution is based on repeated algorithm of a weighted lasso application. We used 5-fold cross-validation for fitting our model and set the penalization parameter lambda to the number in which the cross-validation error was minimalized.

\subsection{Random Forest}

The algorithm for inducing a random forest was developed by Breiman and Cutler (Breiman, 2000). Random forest is a machine learning ensemble classifier that consists of many decision trees and outputs the class that is the mode of the class's output by individual trees. It preserves advantages of classification trees. First, it is inherently non-parametric method, so no assumptions are made regarding the underlying distribution of values of the predictor variables. Thus, it can handle numerical data that are highly skewed or multi-modal, as well as categorical predictors with either ordinal or non-ordinal structure. Second, it can be used if the number of variables is bigger than number of cases. Moreover, it is not prone to over fitting. The classification ability of fitted models is estimated using OOB (out of bag) classification error. Its implementation can be found in statistical system R (R Core Team, 2014), package randomForest (Liaw, 2002).

\section{Data}

We illustrate our approach using two datasets of Slovak companies. The first data set was extracted from the database provided by INFIN, s.r.o, Bratislava in 2007, (currently CRIF Slovak Credit Bureau, s.r.o) and consists of financial data - 36 financial ratios (see Table 1) from 190 Slovak industrial companies active in different industrial sectors (category $\mathrm{C}$ according to SK NACE classification), 55 of them labeled as being in distress. A company was labeled as a company in financial distress if it went bankrupt or has liabilities to Social Insurance Agency or 
health insurance companies. Data covers the period 2002 - 2004. This data set was already used for bankruptcy modeling in (Král' et al., 2007) and (Stachová et al., 2010).

Table 1. Financial predictors for dataset 1.

\begin{tabular}{|c|c|c|}
\hline Loans to debt ratio & Gross return on sales & Value added to sales ratio \\
\hline Cash-flow to sales ratio & Net income to current liabilites ratio & Operating profit margin \\
\hline Total debt ratio & Cash-flow to debt ratio & Return on sales \\
\hline Inventory turnover ratio & Operating assets to debt ratio & Assets to debt ratio \\
\hline $\begin{array}{l}\text { Accounts short-term trade } \\
\text { receivable turnover ratio }\end{array}$ & Operating assets to current liabilities ratio & EBITDA debt coverage \\
\hline $\begin{array}{l}\text { Accounts short-term trade } \\
\text { payable turnover ratio }\end{array}$ & Current liabilities to assets ratio & Interest coverage ratio \\
\hline Long-term debt ratio & CF-based liquidity ratio & Loans to assets ratio \\
\hline Operating return on assets & Cash ratio & $\begin{array}{l}\text { Equity to assets ratio } \\
\text { Equity to long-term debt }\end{array}$ \\
\hline EBITDA to sales ratio & Quick ratio & ratio \\
\hline Financial leverage & Current ratio & Average settlement period \\
\hline Financial leverage - modified & Asset turnover ratio & Average collection period \\
\hline Gross return on assets & Newly value added to sales ratio & Return on equity \\
\hline
\end{tabular}

Source: Author's work.

Table 2. Financial predictors for dataset 2.

\begin{tabular}{|c|c|c|}
\hline Net profit to asset ratio & Gross return on sales & Value added to sales ratio \\
\hline Cash-flow to sales ratio & Net income to current liabilites ratio & Maturity of claims \\
\hline Total debt ratio & Cash-flow to debt ratio & Return on sales \\
\hline Gross assets rentability & Operating assets to debt ratio & Assets to debt ratio \\
\hline Assets turnover ratio & $\begin{array}{l}\text { Operating assets to current liabilities } \\
\text { ratio }\end{array}$ & Maturity of receivables \\
\hline $\begin{array}{l}\text { Short-term trade accounts } \\
\text { payable turnover ratio }\end{array}$ & Net working capital to total assets ratio & Interest coverage ratio \\
\hline Long-term debt ratio & Retained earings to total assets ratio & Loans to assets ratio \\
\hline Operating return on assets & Cash ratio & Equity to assets ratio \\
\hline EBITDA to sales ratio & Quick ratio & $\begin{array}{l}\text { Equity to long-term debt } \\
\text { ratio }\end{array}$ \\
\hline Financial leverage & Current ratio & $\begin{array}{l}\text { Operating return on sale } \\
\text { ratio }\end{array}$ \\
\hline $\begin{array}{l}\text { Common capital to foreign } \\
\text { sources ratio }\end{array}$ & Asset turnover ratio & $\begin{array}{l}\text { Short-term liabilities to total } \\
\text { liabilities ratio }\end{array}$ \\
\hline Inventory turnover & Maturity of trade payables & Assets to average debt ratio \\
\hline $\begin{array}{l}\text { Flow indebted } \\
\text { Maturity of trade } \\
\text { receivables }\end{array}$ & Newly value added to sales ratio & Return on equity \\
\hline
\end{tabular}

Source: Author's work.

The second data set covers the years 2009 and 2010. It consists of 52 Slovak companies, 26 of them labeled as being in distress, and 40 financial ratios (see Table 2). Company was labeled 
as being in distress if its economic valued added (EVA) was negative, its payment discipline was scored from CCC (risky) to D (bankruptcy) and a negative event occurred, e.g. existence of liabilities to Social Insurance Agency or health insurance companies etc. Data was partially extracted from CRIBIS data base (provided by CRIF - Slovak Credit Bureau, s.r.o). More detailed description of data as well as application of well-known financial distress models to it can be found in (Gundová, 2014).

\section{Results}

We applied methodology described in previous section to both data sets separately. In order to preserve as many variables as possible we decided to remove missing values list wise, e.g. cases (companies) with at least one missing financial ratio were removed from our analysis. In the first case it resulted to reduction of companies to 175 (45 of them being in distress). The second data set remained the same as no missing values were present there. We computed new variables representing changes in financial ratios. In the first case as we subtracted financial ratios in 2002 from financial ratios in 2003. In the second case we subtracted financial ratios in 2009 from financial ratios in 2010. In both cases there were high pairwise correlations between variables. Moreover, in the second case the number of variables exceeds the number of cases. Therefore we applied PCA (assuming correlation matrix) in both cases. In the case of data set 2 we started with PCA applied to original variables and then continued by applying PCA to new variables representing changes in financial ratios. In both cases we selected components preserving at least $90 \%$ of variability of original data. The resulting sets of linearly independent components were then assumed as new sets of predictors. For data set 2 there were neither high pairwise correlation coefficient between components from these two groups nor a serious multicollinearity problem (except components 1 and 13). The multicollinearity was checked using function vif() included in $\mathrm{R}$ package named $\mathrm{HH}$ (Heiberger, 2014). In the final stage of analysis we fitted penalized logistic regression models to both data sets with principal components and random forest models to data sets with original variables. We constructed two classifiers for each data set and each method - one assuming changes in financial ratios, i.e. data set with added differences, and one without them. The detailed results of principal component analysis (loadings of variables, explained variance etc.) and fitted models as well as the corresponding $\mathrm{R}$ code are omitted here but they are available at http://1drv.ms/1lk6nK2 or upon request from authors. The classification quality of the fitted models is summarized in confusion matrices (see Table 4 - 6). Columns represent the instances in predicted classes, while rows represent the instances in actual classes. Thus, the diagonal elements represent correctly classified cases and the cross-diagonal elements represent misclassified cases. Prediction ability was estimated using cross-validation techniques in all cases. It is easy to see that prediction quality of classifier based on penalized logistic regression outperforms classifier based on random forest in all presented cases. Moreover, inclusion of changes decreased classification error from 2 to 13 percentage points ( 2 and 3 percentage points for data set 1 and 13 and 3 percentage points for data set 2). The better performance of penalized logistic regression could be a consequence of multicollinearity in original data leading to correlation between individual trees and thus inferior prediction ability of random forest. 
Table 3. Confusion matrix of penalized logistic regression and random forest without changes in financial ratios in data set 1

\begin{tabular}{ccccc}
\hline & \multicolumn{4}{c}{ Predicted class } \\
& \multicolumn{2}{c}{ Penalized logistic regression } & \multicolumn{2}{c}{ Random forest } \\
\cline { 2 - 5 } Actual class & in distress & not in distress & in distress & not in distress \\
\cline { 2 - 5 } in distress & 12 & 6 & 12 & 33 \\
not in distress & 33 & 124 & 17 & 113 \\
& Cross validation error: & $22 \%$ & OOB error: & $29 \%$ \\
\hline
\end{tabular}

Source: Author's work.

Table 4. Confusion matrix of penalized logistic regression and random forest with changes in financial ratios for data set 1

Predicted class

Penalized logistic regression Random forest

\begin{tabular}{cccrc} 
Actual class & in distress & not in distress & in distress & not in distress \\
\cline { 2 - 5 } in distress & 17 & 7 & 16 & 16 \\
not in distress & 28 & 123 & 29 & 114 \\
& Cross validation error: & $20 \%$ & OOB error: & $26 \%$ \\
\hline
\end{tabular}

Source: Author's work.

The next confusion matrices come from the second data set.

Table 5. Confusion matrix of penalized logistic regression and random forest without changes in financial ratios for data set 2

\begin{tabular}{ccccc}
\hline & \multicolumn{4}{c}{ Predicted class } \\
Actual class & \multicolumn{2}{c}{ Penalized logistic regression } & \multicolumn{2}{c}{ Random forest } \\
\cline { 2 - 5 } in distress & not in distress & in distress & not in distress \\
\cline { 2 - 5 } not in distress & 24 & 8 & 18 & 12 \\
& 2 & 18 & 8 & 14 \\
& Cross validation error: & $19 \%$ & OOB error: & $38 \%$ \\
\hline
\end{tabular}

Source: Author's work.

Table 6. Confusion matrix of penalized logistic regression and random forest with changes in financial ratios for data set 2

\begin{tabular}{ccccc}
\hline & \multicolumn{4}{c}{ Predicted class } \\
Actual class & \multicolumn{2}{c}{ Penalized logistic regression } & \multicolumn{2}{c}{ Random forest } \\
\cline { 2 - 5 } in distress & not in distress & in distress & not in distress \\
\cline { 2 - 5 } in distress & 25 & 2 & 17 & 9 \\
not in distress & 1 & 24 & 9 & 17 \\
& Cross validation error: & $6 \%$ & OOB error: & $35 \%$ \\
\hline
\end{tabular}

Source: Author's work.

Finally, we compare resulting cross-validated classification errors to classification errors without model, i.e. the errors we get assigning all companies to a larger group in the corresponding data set. For the first data (45 companies in distress, 130 companies not in distress) it means that we classify all companies as not being in distress. In that case 45 
companies are not classified correctly and we get the overall prediction error approximately $26 \%$. This classification error then serves as a basic benchmark for classification models constructed using the first data set. Analogously, for the second data set (26 companies in distress, 26 companies not in distress) we have the classification error without model $50 \%$. Using penalized logistic regression there was a decrease in classification error by 4 (6) percentage points in the case of the first data set without (with) incorporated changes and by 31 (44) percentage points in the case of the second data set without (with) incorporated changes in financial ratios. For classifiers based on random forest it was -3 (0) and 12 (15) percentage points, respectively.

\section{Conclusion}

In the paper we propose a simple methodology how to incorporate minimal knowledge about the changes in financial ratios to a classical static corporate financial distress modelling. As far as we know, such models have not yet been constructed for economic environment in Slovakia. We applied our methodology on two different sets of Slovak industrial companies representing the period 2002-2004 and 2009-2010, respectively, using classification based on penalized logistic regression and random forests. We compared the resulting classifiers to those fitted in the classical way, i.e. without including changes in financial ratios. Results of our analysis indicate that the proposed methodology provides us by improvement in prediction ability of our models, but it can be a minor one. As usual, it is matter of data quality, i.e. it depends on information embedded in our data set. If quantitative characteristics of companies in the two consecutive time points are similar to each other, differences do not provide us with relevant information for improving classification. In our opinion it is worth to verify the proposed methodology in a longer period by comparing models fitted in many time points of that period with respect to prediction quality, time stability and variables included in the model.

\section{Acknowledgements}

Mária Stachová and Pavol Král' have been supported by the project VEGA 1/0647/14.

This work was supported by projects Mobility - enhancing research, science and education at Matej Bel University, ITMS code: 26110230082, under the Operational Program Education co-financed by the European Social Fund.

\section{References}

1. ALTMAN, E. I. 1968. Financial ratios, discriminant analysis and the prediction of corporate bankruptcy. In The Journal of Finance, 1968, vol. 23, iss. 4, pp. 589-609.

2. BALCAEN, S., OOGHE, H. 2006. 35 Years of Studies on Business Failure: an Overview of the Classic Statistical Methodologies and Their Related Problems, In. The British Accounting Review, 2006, vol. 38, issue 1, pp. 63-93.

3. BATES, D., MAECHLER, M. 2012. MatrixModels: Modelling with Sparse And Dense Matrices. R package version 0.3-1. http://CRAN.R-project.org/package=MatrixModels

4. BREIMAN, L. 2000. Random Forests, Machine Learning, 2000, vol. 45, iss. 1, pp. 5-32. ISSN 1573-0565.

5. BREZIGAR-MASTEN, A., MASTEN, I. 2012. CART-based selection of bankruptcy predictors for the logit model, In. Expert Systems with Applications, 2012, vol.39, issue 11, pp. 10153-10159. 
6. FRIEDMAN, J., HASTIE, T., TIBSHIRANI, R. 2010. Regularization Paths for Generalized Linear Models via Coordinate Descent, In. Journal of Statistical Software, 2010, vol. 33, issue 1, pp. 1-22.

7. GUNDOVÁ, P. 2014. Využitie klasifikačných modelov pre potrebu predikcie úpadku podniku. In Scientia Iuventa 2014. Zborník príspevkov z medzinárodnej doktorandskej konferencie. Banská Bystrica: Belianum. 2014, pp. 124-131. ISBN 978-80-557-0700-6.

8. HASTIE, T., FRIEDMAN, J. H., TIBSHIRANI, R. 2001. The Elements of Statistical Learning, New York: Springer. 2001. ISBN-13 978-0387848570.

9. HEIBERGER, R. M. 2014. HH: Statistical Analysis and Data Display: Heiberger and Holland. R package version 3.0-4. URL http://CRAN.R-project.org/package=HH

10. HERNANDEZ, M. H., WILSON, N. 2013. Financial distress and bankruptcy prediction among listed companies using accounting, market and macroeconomic variables. In International Review of Financial Analysis, 2013, vol. 30, pp. 394-419.

11. JAMES, G. et al. 2013. An Introduction to Statistical Learning with Applications in R. New York: Springer. 2013. ISBN 978-1-4614-7137-0.

12. KRÁL, P., HIADLOVSKÝ, V., GAVLIAK, R. 2007. Použitie faktorovej analýzy pri predikcii finančnej situácie podnikov v SR s využitím SPSS. In Forum Statisticum Slovacum, 2007, vol. 3., iss. 4, pp. 74-79, ISSN 1336-7420.

13. LIAW, A., WIENER, M., 2002. Classification and Regression by randomForest, R News, vol. 2, iss. 3, pp. 18-22, 2002.

14. R CORE TEAM 2013: R: a language and environment for statistical computing. Vienna: R Foundation for Statistical Computing, 2012, http://www.r-project.org/.

15. STACHOVÁ, M., KRÁL, P. 2010, Predicting financial distress of Slovak companies using data mining techniques, In. AMSE 2010 Proceedings, Banská Bystrica: OZ Finance, pp. 334-343, ISBN 978-80-89438-02-0.

16. TINOCO, M. H., WILSON, N. 2013. Financial distress and bankruptcy prediction among listed companies using accounting, market and macroeconomic variables, In. International Review of Financial Analysis, vol. 30, pp. 394-419. 